\title{
The Exploration of Young Prisoners Social Anxiety
}

\author{
Alizamar Alizamar ${ }^{(1)}$ Afdal Afdal, ${ }^{(2)}$ Miftahul Fikri, ${ }^{(3)}$ \\ ${ }^{123}$ Universitas Negeri Padang, Padang - Indonesia, (miftahulfikri33@gmail.com)
}

\begin{abstract}
One of the problems experienced by young prisoners is the fear of exaggeration and anxiety unacceptable in the social environment after being released from prison, also called social anxiety. The purpose of this study was to look at the image of social anxiety of young prisoners. This research uses descriptive method with quantitative approach. The sampling method is the total sampling. The sample of this research is all of juvenile inmates at Institution of Special Grade of Children Class II Tanjung Pati amounted to 33 people. Data collection using young prisoner social anxiety scale with reliability of 0.86 with high category. The results showed that the prisoners' social anxiety image was in the high category with the percentage of $51.52 \%$. This means the need for special guidance provided by prison counselors to reduce social anxiety experienced by Young Prisoners
\end{abstract}

Keywords: social anxiety, young prisoners

This is an open access article distributed under the Creative Commons 4.0 Attribution License, which permits unrestricted use, distribution, and reproduction in any medium, provided the original work is properly cited. (C2018 by author and Faculty of education, Universitas Negeri Padang.

\section{Introduction}

The problem of adolescents today, the change of adolescent values and morals is increasingly worrying (Puspitawati, 2006). Changes in the values and morals of the natural teenager, not infrequently the teenagers fall into the negative direction (Santrock, 2007, Papalia, Olds \& Feldman, 2009; Chaplin, 2011) such as taking legal action that resulted in juvenile entry into prison. Penalties received by adolescents are regulated in Law No. 11 of 2012 on the Juvenile Justice System. The law implies citizens who commit crimes, aged 12-18 years, still categorized as children and received special treatment. While in prison there are some problems facing juvenile inmates ranging from personal, social, learning, and career. One of the problems faced by young prisoners in the social field is the feeling of fear and excessive worry with the society or social environment when it will be free to undergo a period of punishment and better known as social anxiety or social anxiety when it will be free. Even though a teenager is already in prison, it is possible that after being released he will become a useful person in the community later on.

Furthermore, based on the results of interviews with young prisoners it appears that the inmates are shaking and afraid to meet new people, wanting to avoid meeting new social environment. Furthermore, interviews conducted to prison counselors say that some young prisoners feel overwhelmed when they meet new people, feel they are not considered by people. The results of Sagalokova Truevtsev, \& Sagalakov (2016) also found that from 7 to 16\% of the population in modern western societies have symptoms of social anxiety. Adolescents in this young prisoners have excessive social anxiety tend to recognize their excessive fear, tend to embarrass themselves when 
interacting with others (Root, 2000; Damer, Latimer, \& Porter, 2010). Some of the symptoms of social anxiety are somatic symptoms characterized by a red face due to embarrassment, sweating, palpitations, depressed stomach and panic in social situations (Abdollahi, Talib, Mobarakeh, Momtaz, \& Mobarake, 2015; Bandelow \& Stein, 2004; Nevid , Rathus \& Greene, 2005; Kearney, 2005; Careney \& Edingner, 2010), subsequent cognitive symptoms characterized by unpleasant thoughts on the circumstances (Bandelow \& Stein, 2004; Mawandha \& Ekowarni, 2017), and behavioral symptoms to hide reactions, difficulty speaking, avoiding eye contact, anxiety, and avoiding scary situations (Abdollahi, Talib, Mobarakeh, Momtaz, \& Mobarake, 2015; Bandelow \& Stein, 2004).

Social anxiety is a problem that often occurs in adolescents, and can hamper the stage of optimal development, especially on social development especially teenagers who are in young prisoners (Kearney, 2005). Based on the result of the theoretical and obrservation studies conducted, the researcher wanted to see the description of the social anxiety of young prisoners at the Institution of Special Guidance of the Second Grade Children of Tanjung Pati so that the coach can provide specific strategies / alternative solutions that can be done to help young prisoners in overcoming the problems with social anxiety after serving a time of punishment.

\section{Method}

This research method is descriptive quantitative, by using total sampling technique that is all convict teenager class II Tanjung Pati amounting to 33 adolescent prisoners. The data collection instrument uses the Young Prisioner Social Anxiety Scale.

\section{Results and Discussion}

Results of data collection of problem social anxiety young Prisoner can be viewed in table 1

Table 1. Social Anxiety of Young Prisoners $(n=33)$

\begin{tabular}{cllccc}
\hline No & & Categori & Interval & F & $\%$ \\
1. & Very high & $105-125$ & 1 & 3.03 \\
2. & High & $85-104$ & 17 & 51.52 \\
3. & Enough & $65-84$ & 12 & 36.36 \\
4. & Low & $45-64$ & 3 & 9.09 \\
5. & Very low & $25-44$ & 0 & - \\
\hline
\end{tabular}

In Table 1 shows young prisoners experiencing social anxiety in the high category with a percentage of $51.52 \%$ (17 Young Prisoners) in other words half of Young Prisoners have problems in the social aspects of social anxiety, in the category of sufficient percentage of $36.36 \% 12$ Young Prisoners) are seen to have social problems. Overall Young Prisoners experience problems in the social field in high category.

Based on the results of this study illustrates that in the social field of young prisoner have a problem that can be said high. One of the phenomena that occurs in the social field of young Prisoners is likely to feel anxious and avoid to interact with the community or others because the teenager realizes that he has been alienated for so long from his social environment or better known as social anxiety. According to Kearney (2005) social anxiety is a strong physiological passion in social situations involving possible evaluation by others, with fear or fear of psychological dangers and a desire to escape or avoid social situations. Further Nichols (Yousaf, 2015: 140) explains social anxiety is "fear of being judged and evaluated negatively by other people, leading to feelings of inadequacy, 
inferiority, embarrassment, humiliation, and depression". Explanation above interpreted social anxiety a person is characterized by feelings of fear, inadequacy, low self-esteem, embarrassment, humiliation, and depression to interact with others. Similarly, Diagnostic and Statistical Manual of Mental Disorder (Sagalakova, Truevtsev, \& Sagalakov, 2016) defines that social anxiety disorders as a disorder that makes a person feel afraid, anxious and avoid in situations of social interaction such as: more focus on self-attention when dealing with other people. Social anxiety will also have an impact on the decline in welfare and quality of life wrong, as well as the lack of social role function and career development (Wittchen \& Fehm, 2003; Festa \& Ginsburg, 2011). High social anxiety will tend to cause; a) anxious responses such as cold sweat, trembling and others (Aminullah, 2013; Muarifah, 2012), b) difficulty communicating like a stutter, forgetting to say appropriate sentences or not being able to say what they think, c) avoiding contact with social situations both physically and psychologically (avoidance behavior) such as little talk, little eye contact, or withdrawal, high social anxiety in adolescents avoiding social situations that cause them to be distressed (Biggs, Vernberg \& $\mathrm{Wu}, 2012$ ), and d) behavior that masked the self-image (self image) of its incapacity (Nainggolan, 2011). So social anxiety is the fear and fear of excessive juvenile inmates leading to avoidance behavior in situations of social interaction, focusing on self-attention, and avoiding doing activities in front of others. Special strategies should be used to overcome the problems experienced by juvenile inmates in the social field.

This study also shows 6 issues of highest social anxiety among juvenile inmates compiled in table 2 below:

Table 2. The Highest Problem on Social Sector

\begin{tabular}{rllll}
\hline No & Item Problems & Mean & \% Mean & Classification \\
1. & Considered arrogant & 4,27 & 85,45 & Very High \\
2. & Not good at hanging out & 4,06 & 81,21 & Very High \\
3. & Difficult to work together. & 4,00 & 80,00 & High \\
4. & $\begin{array}{l}\text { Feel unsafe; there is a disturbing or } \\
\text { threatening. }\end{array}$ & 4,00 & 80,00 & High \\
5. & $\begin{array}{l}\text { Family members do not accept my } \\
\text { current condition }\end{array}$ & 3,76 & 75,15 & High \\
6. & $\begin{array}{l}\text { Lack of knowledge about social } \\
\text { manners }\end{array}$ & 3,73 & 74,55 & High
\end{tabular}

Table 2 presents the highest inventory-finding results in the social field of 33 young prisoners and adolescent people, it was recognized that the highest score on the problem item "Considered arrogant", with an average score of 4.27 with a percentage of $85.45 \%$ belonging to the very high category. This relates to social anxiety in behavioral symptoms showing attempts to hide reactions, avoiding eye contact with others (Bandelow \& Stein, 2004: 2). Furthermore, the item "not good at associating" with an average score of 4.06 with a percentage of $81.21 \%$, this can be related to behavioral symptoms with the characteristics of withdrawal when meeting new people (Kearney, 2005). Next on the item "It's hard to work together and feel insecure; there is a disturbing or threatening ", having an average score of 4.00 with $80.00 \%$, this is related to cognitive symptoms in social anxiety in thoughts that are negative evaluations with self-threatening things (Kearney, 2005; Suryaningrum, 2013). Furthermore the problem item "Family members do not accept my current condition", with an average score of 3.76 with percentage of $75.15 \%$ it is related to cognitive symptoms in social anxiety with negative feelings that consider themselves no longer in the mind of the family (Kearney, 2005). Furthermore, on the problem item "Lack of knowledge about social manners" with an average score of 3.73 with a percentage of $74.55 \%$, this is similar to the understanding of adolescents that there are physical changes and psychological development (Santrock, 2007), in this case the child needs to understand and developmental tasks in terms of social 
maturity when interacting with others (Jahja, 2013). therefore serious services need to be undertaken by experts such as counselors who can help social anxieties of young prisioner (Alizamar, Fikri, \& Afdal, 2017).

\section{Conclusions}

Based on the results of this study, the image of social anxiety of young prisoner in the LPKA Tanjung Pati is in High category with $51.52 \%$ percentage and enough category with $36.33 \%$ percentage. This indicates a social anxiety that the young prisoner experienced after his release from prison. There needs to be a special strategy that can be done to handle social anxiety experienced by young prisoners such as making a teaching material or media module that can be used by coaches or experts such as counselors in overcoming social anxiety.

\section{Acknowledgments}

This study is a sub-study of post-UNP research grants. This article was limited to see the picture of social anxiety young prisioner.

\section{References}

Alizamar, A., Fikri, M., \& Afdal, A. (2017). Social Anxiety of Youth Prisoners and Guidance and Counseling Services for Prevention. Jurnal Psikologi Pendidikan dan Konseling: Jurnal Kajian Psikologi Pendidikan dan Bimbingan Konseling, 30-36.

Abdollahi, A., Talib, M. A., Mobarakeh, M. R. V., Momtaz, V., \& Mobarake, R. K. (2015). Body-esteem mediates the relationship between self-esteem and social anxiety : The moderating roles of weight and gender. Child Care in Practice, 1(1), 1-14. https://doi.org/10.1080/13575279.2015.1054787.

Aminullah, M. A. (2013). Kecemasan antara Siswa SMP dan Santri Pondok Pesantren. Jurnal Ilmiah Psikologi Terapan, 1(2), 205-215.

Bandelow, B \& Stein, J. D. (2004). Social Anxiety Disorder. New York: Marcel Dekker, Inc

Biggs, B. K., Vernberg, E. M., \& Wu, Y. P. (2012). Social Anxiety and Adolescents ' Friendships : The Role of Social Withdrawal. Jornal of Early Adolescence, 32(6), 803-823. https://doi.org/10.1177/0272431611426145

Chaplin, J. E. (2011). Kamus Lengkap Psikologi. Terjemahan oleh Kartini Kartono. Jakarta: Raja Grafindo Persada.

Damer, D. E., Latimer, K. M., \& Porter, S. H. (2010). The Journal for Specialists in Group Work “ Build Your Social Confidence ": A Social Anxiety Group for College Students. The Journal for Specialists in Group Work, 35(1), 37-41. https://doi.org/10.1080/01933920903463510

Festa, C. C., \& Ginsburg, G. S. (2011). Parental and Peer Predictors of Social Anxiety in Youth. Child Psychiatry Hum Dev, 42(1), 291-306. https://doi.org/10.1007/s10578-011-0215-8

Jahja, Y. (2013). Psikologi Perkembangan. Jakarta: Kencana Media Grup.

Kearney, A. C. (2005). Social Anxiety and Social Phobia in Youth. Las Veges, Nevada: Springer Science+ Business media, Inc.

Muarifah, A. (2012). Hubungan kecemasan dan agresivitas. Humanitas: Indonesian Psychological Journal, 2(2), 102-112.

Mawandha, H. G., \& Ekowarni, E. (2017). Terapi Kognitif Perilaku dan Kecemasan Menghadapi Prosedur Medis Pada Anak Penderita Leukemia. JIP: Jurnal Intervensi Psikologi, 1(1), 75-92.

Nainggolan, T. (2011). Hubungan Antara Kepercayaan Diri Dengan Kecemasan Sosial Pada Pengguna Napza: penelitian di balai kasih sayang parmadi siwi. Sosiokonsepsia, 16(2), 161-174. 
Nevid, J. S., Rathus, S. A., \& Greene, B. (2005). Psikologi Abnormal. Edisi ke Lima. Jilid 1. Jakarta: Erlangga.

Papalia, D. E., Olds, S.W., \& Feldman, R.D. (2009). Human Development. Jakarta: Salemba Humanika. Puspitawati, H. (2006). Pengaruh Faktor Keluarga, Lingkungan Teman dan Sekolah terhadap Kenakalan Pelajar di Sekolah Lanjutan Tingkat Atas (SLTA) di Kota Bogor.

Root, B. (2000). Understanding Panic and Other Anxiety Disorders. USA: University Press of Mississippi.

Suryaningrum, C. (2013). Cognitive Behavior Therapy (CBT) Untuk Mengatasi Gangguan Obsesif Kompulsif. Jurnal Ilmiah Psikologi Terapan, 1(1), 1-11

Sagalakova, O. A., Truevtsev, D. V, \& Sagalakov, A. M. (2016). Cognitive and Perceptual Selectivity and Target Regulation of Mental Activity in Personal Evaluation Situations of Social Anxiety Disorder. journal of environmental \& science education, 11(12), 5049-5057.

Santrock, J. W. (2007). Adolescence (Eleventh Edition). Terjemahan oleh Benedictine Widyasinta. Jakarta: Erlangga.

Wittchen, H. U., \& Fehm, L. (2003). Epidemiology and natural course of social fears and social phobia. Acta Psychiatrica Scandinavica, 108(417), 4-18.

Yousaf, S. (2015). The Relation between Self-esteem , Parenting Style and Social Anxiety in Girls. Journal of Education and Practice, 6(1), 140-143. 